\title{
What are the Indications for Mitral Valve Replacement?
}

\author{
J. R. BELCHER,* M.S., F.R.C.S.
}

Now that it is possible to treat mitral valve disease by valve replacement as well as by commissurotomy, and now that it is relatively simple to have either method readily available, it is most important to know which valves should be replaced and which can be safely treated by valvotomy. When the surgeon palpates the valve at operation he may feel stenosis, regurgitation, calcification, or any combination of these three, and he has to decide there and then which of the two methods is called for. This paper makes an attempt to answer this question.

\section{Introduction}

When a new operation is introduced it tends to gather momentum as it becomes established, and early results may lead to overenthusiasm for it. As the time passes disillusion may set in as the disadvantages as well as the advantages become apparent, and only then can it find its correct place in the surgeon's armoury. This pattern has been common with cardiac operations, and is now being seen with the use of prostheses in the treatment of mitral valve disease.

It has been suggested Effler et al. (1965) that restenosis is an indication for valve replacement, that heavy calcification is apt to lead to poor results after simple valvotomy, and that where a mitral valve is incompetent it should be replaced.

The results of second operations for mitral stenosis, though not as good as those of primary ones, are adequate (Belcher and Gupta, 1964), and valve prostheses would have to show themselves to be much more trouble-free than they are now before it could be established that they could produce results superior to those of simple transventricular valvotomy. It is therefore not proposed to discuss this indication further here. The bases of the other two indications have been studied.

Surgical treatment of mitral valve disease was established many years before the advent of the bypass techniques which enabled surgeons to consider valve replacement. During this time many patients with valves which might now be considered for replacement were treated by valvotomy. A study of those patients who had a valvotomy between 1952 and the end of 1960 has been made; they had one or more of three conditions -namely, mitral incompetence before operation, mitral incompetence after valvotomy, or heavy calcification of the valve. The long-term results in these groups are compared with those in patients who had a valvotomy during the same period but had neither incompetence nor heavy calcification of the valve.

\section{Method and Material}

In all, the records of 402 patients were studied. Ail had their primary operation between 1952 and the end of 1960, mostly by the knife-and-finger-fracture method; some subsequently had second and even third operations. The great majority were seen in the outpatient department during the past year, but some who live at a distance were contacted either

* Middlescx and London Chest Hospitals. by post or through their doctor. Touch was lost with 32, either because of their departure abroad or for administrative reasons ; of these, 17 were in the group with simple mitral stenosis, and 15 were in the other groups under consideration-proportions roughly similar to those of the group the follow-up for which is available.

The method of assessment of the results was essentially subjective, coupled with observation of signs of congestive failure when these were present. This method is open to criticism, but the same criteria were used for each group and such objective methods of assessment as E.C.G. changes, radiographic changes, and the alteration of the character of the murmurs are notoriously unreliable, and catheter studies were clearly out of the question in a series of this size. Exercise-tolerance tests were not done.

Operative death was defined as death in hospital after operation. Late death is self-explanatory, but many patients in this group clearly died of restenosis. Restenosis was defined as stenosis severe enough to justify a second operation, and for that operation to have been done. Exercise tolerance was assessed at the last follow-up attendance, and was put into one of four categories: " excellent," " good," "fair," or " poor.” All patients who subsequently had valve replacement or repair were pur into the "poor" group. For the purposes of this paper the first two were included under one heading and the last two were also combined. The number of poor results depended largely on the efficiency of the follow-up and the selection of patients for surgery. Any patient found to have a poor result at follow-up who had deteriorated after initial improvement was considered for a second valvotomy, and those who had been found to have dominant mitral incompetence were considered for valve replacement. Because of the completeness of the follow-up the numbers in this category are small.

Calcification was considered when it had been described as "heavy" on palpation at operation; minor degrees, though frequent, were not included. The degree of regurgitation was also assessed by palpation at operation, both before and after valvotomy. It was put into one of three grades. . The term "grade 1 " was used when the regurgitant jet was just palpable, "grade 2 " when it was easily palpable but was not thought great enough to be haemodynamically significant (there might have been differences of opinion between surgeons about patients in this group), and "grade 3 " when the regurgitation was obviously severe. The shortcomings of this method of assessment do not need emphasis, but it is probably still the best available.

\section{Mitral Incompetence before Operation}

In all there were 117 patients for assessment in this group ; this number included 45 in whom there was also heavy calcification. Seven patients whose regurgitation was worsened by valvotomy were not included. In 89 the regurgitation was not thought to be haemodynamically significant on palpation (grades 1 and 2), but in 28 it was severe. It may be asked why the latter patients were subjected to an operation. In a few an underestimate of the severity of the incompetence before 
operation was responsible, but in the remainder, all of whom were severely disabled, exploration was thought justified either in case tight stenosis was present, despite the physical signs of incompetence, or in the hope that commissurotomy, even in the face of severe incompetence, might lead to some amelioration of the symptoms (Belcher, 1956).

TABLE I.-Results in Patients with Mitral Incompetence Before Operation or with Simple Mitral Stenosis

\begin{tabular}{c|c|c|c|c|c|c|c}
\hline & Total & $\begin{array}{c}\text { Op. } \\
\text { Death }\end{array}$ & $\begin{array}{c}\text { Late } \\
\text { Death }\end{array}$ & $\begin{array}{c}\text { Re- } \\
\text { stenosis }\end{array}$ & Good & Poor & Lost \\
\hline $\begin{array}{c}\text { No } \\
\text { M.I. }\end{array}$ & 21.4 & $15(7 \%)$ & $22(11 \%)$ & $60(30 \%)$ & $74(37 \%)$ & $26(13 \%)$ & $17(8 \%)$ \\
$\begin{array}{c}\text { Grade } \\
1 \\
\text { Grade } \\
2\end{array}$ & 53 & $3(6 \%)$ & $11(22 \%)$ & $16(32 \%)$ & $13(26 \%)$ & $6(12 \%)$ & $4(8 \%)$ \\
$\begin{array}{c}\text { Grade } \\
3\end{array}$ & 36 & $3(8 \%)$ & $10(30 \%)$ & $10(30 \%)$ & $6(18 \%)$ & $3(9 \%)$ & $4(12 \%)$ \\
\hline \multicolumn{6}{c|}{ Percentages given are of those surviving operation. }
\end{tabular}

Table I shows the results. Each patient had the regurgitation graded before any attempt was made to undertake valvotomy. The results are compared with those of the 214 patients with pure stenosis. The figures show that the presence of incompetence had no influence on the operative mortality, but had a considerable influence on the number of late deaths. These rose steadily as the severity of the incompetence increased, until three-quarters of those with severe incompetence were found to be dead. On the other hand, the proportion of patients who were thought to have a good result was highest in those with no incompetence and fell steadily as the grade of incompetence increased, there being only one in this category among those with severe leaks. For reasons already given, the proportions with poor results were much the same in each group. The incidence of restenosis was almost the same in the first three groups, but, rather surprisingly, there were four patients who undoubtedly had severe incompetence when they were first operated on, and who, at their second operation, two of which were open, were found to have dominant stenosis.

It was thought possible that the association of heavy calcification with the incompetence in 45 cases might be chiefly responsible for the poor results. Table II compares the groups when patients with heavy calcification have been excluded. It can be seen that, though the results in grade 1 regurgitation now approached those in patients with pure stenosis, the results in the other two groups were very little affected by the withdrawal of those patients with heavily calcified valves.

TABlE 1I.-Results in Patients Where There was no Calcification of Other Valves

\begin{tabular}{l|c|c|c|c|c|c|c}
\hline & Total & $\begin{array}{c}\text { Op. } \\
\text { Death }\end{array}$ & $\begin{array}{c}\text { Late } \\
\text { Death }\end{array}$ & $\begin{array}{c}\text { Re- } \\
\text { stenosis }\end{array}$ & Good & Poor & Lost \\
\hline \begin{tabular}{c|c} 
No \\
M.I.
\end{tabular} & 194 & $12(6 \%)$ & $20(11 \%)$ & $53(29 \%)$ & $71(40 \%)$ & $21(11 \%)$ & $17(9 \%)$ \\
$\begin{array}{c}\text { Grade } \\
1\end{array}$ & 40 & $3(7 \%)$ & $4(11 \%)$ & $12(33 \%)$ & $12(33 \%)$ & $5(13 \%)$ & $4(11 \%)$ \\
$\begin{array}{c}\text { Grade } \\
2\end{array}$ & 17 & 1 & $5(31 \%)$ & $3(19 \%)$ & $3(19 \%)$ & $2(12 \%)$ & $3(19 \%)$ \\
$\begin{array}{c}\text { Grade } \\
3\end{array}$ & 15 & 0 & $13(87 \%)$ & 0 & 0 & $2(13 \%)$ & 0 \\
\hline
\end{tabular}

Table II shows that the presence of grade 1 mitral incompetence before valvotomy does not under present circumstances justify valve replacement, and that this is particularly so when the valve is nor calcified. On the other hand, they show that if severe regurgitation is encountered valve replacement or annuloplasty is essential. Where grade 2 incompetence is felt the position is less clear, as the late death rate is three times that in patients with no incompetence and the good results were achieved in only half as many. When the late morbidity of prosthetic valves falls grade 2 incompetence may well indicate their use, but it is doubtful whether in their present form they should be used in patients in this category.

\section{Mitral Incompetence after Operation}

This group includes all those who had no incompetence before their valvotomy in whom a leak was created, and all those in whom regurgitation was already present when it was thought to have been increased, however slightly. There were 71 such cases, seven of whom had pre-existing incompetence. Table III shows the results. The figures in each group are small, but some conclusions may be drawn from them. The late death rate was essentially the same in each group, though it was higher in those in whom severe incompetence was created. In only one case does it seem from the manner of death that it was due to incompetence that had been underestimated. Again, except for those with severe incompetence, there was little difference among those with poor results, and the higher proportion in the latter group is due to the fact that those in whom open repair was subsequently carried out were included under this heading. One difference between those with and those without incompetence does emerge: restenosis was less common where incompetence had been created, and this difference is reflected in the correspondingly larger number of good results among these patients.

\begin{tabular}{l} 
TABLE III.-Results in Patients with Created Mitral Incompetence \\
\begin{tabular}{c|c|c|c|c|c|c|c}
\hline & Total & $\begin{array}{c}\text { Op. } \\
\text { Death }\end{array}$ & $\begin{array}{c}\text { Late } \\
\text { Death }\end{array}$ & $\begin{array}{c}\text { Re- } \\
\text { stenosis }\end{array}$ & Good & Poor & Lost \\
\hline $\begin{array}{c}\text { No } \\
\text { M.I. }\end{array}$ & 214 & $15(7 \%)$ & $22(11 \%)$ & $60(30 \%)$ & $74(37 \%)$ & $26(13 \%)$ & $17(8 \%)$ \\
$\begin{array}{c}\text { Grade } \\
1\end{array}$ & 27 & 0 & $3(11 \%)$ & $5(18 \%)$ & $12(44 \%)$ & $4(15 \%)$ & $3(11 \%)$ \\
$\begin{array}{c}\text { Grade } \\
2\end{array}$ & 32 & $2(7 \%)$ & $3(10 \%)$ & $3(10 \%)$ & $16(53 \%)$ & $4(13 \%)$ & $4(13 \%)$ \\
$\begin{array}{c}\text { Grade } \\
3\end{array}$ & 12 & 0 & $3(25 \%)$ & $1(8 \%)$ & $4(33 \%)$ & $4(33 \%)$ & - \\
\hline
\end{tabular} \\
\hline
\end{tabular}

Thus where any grade of incompetence was created the results were better than those where the leak preceded the valvotomy. This was particularly true among the patients with grade 3 incompetence. There was no operative mortality in this group -an important and rather surprising finding-and there were only $25 \%$ of late deaths, compared with the $75 \%$ in the patients with severe incompetence before operation. Besides this, onethird have good results, and three of these four now have almost no audible systolic murmur, as it had disappeared gradually with the passage of time.

It thus appears that the creation of either grade 1 or 2 incompetence is certainly not an indication for valve replacement. Secondly, if a severe tear occurs at valvotomy, though valve replacement may be the operation of choice (Belcher, 1964), as suture is unlikely to be successful, conservatism may be justified, and the valve should be replaced only when it is quite certain that the patient would not survive the immediate postoperative period if this were not done.

\section{Calcification of the Valve}

There were 75 patients $(21 \%)$ in whom the valve was described as "heavily calcified" at operation. Of these, 55 have already been considered, as they had mitral incompetence either before or after operation. In some respects they are not comparable with the rest of the cases, as there was a much higher proportion of men ( $53 \%$ as against $13 \%$ ) and a greater proportion had mitral incompetence before operation (60\% as against $21 \%$ ). The results have therefore to be judged in isolation, but as these two differences are always associated with calcified valves the observations about the results should still be taken into account when a decision is being made on whether or not to replace a valve.

The total results after primary operations are shown in Table IV, where they are compared with the results in patients 
with no calcification. With the reservations made about the comparability of the groups, heavy calcification can be seen to have a markedly adverse effect on the results. The proportion

\begin{tabular}{|c|c|c|c|c|c|c|c|}
\hline \multirow{2}{*}{ Valves } & \multicolumn{5}{|c|}{ TABLE IV } & \multirow[b]{2}{*}{ Poor } & \multirow[b]{2}{*}{ Lost } \\
\hline & Total & Op. & $\begin{array}{l}\text { Late } \\
\text { Death }\end{array}$ & $\begin{array}{c}\mathrm{Re}- \\
\text { stenosis }\end{array}$ & Good & & \\
\hline $\begin{array}{l}\text { Calci- } \\
\text { fied } \\
\text { Non- } \\
\text { calci- }- \\
\text { fied }\end{array}$ & $\begin{array}{r}75 \\
327\end{array}$ & $\begin{array}{r}6(8 \%) \\
17(5 \%)\end{array}$ & $\begin{array}{l}22(32 \%) \\
51(16 \%)\end{array}$ & $\begin{array}{l}22(32 \%) \\
77(25 \%)\end{array}$ & $\begin{array}{l}11(16 \%) \\
115(36 \%)\end{array}$ & $\begin{array}{l}12(18 \%) \\
37(12 \%)\end{array}$ & $\begin{array}{c}2(3 \%) \\
30(10 \%)\end{array}$ \\
\hline
\end{tabular}

of late death is double that in patients who had little or no calcification, and good results were less than half as frequent.

When the figures were studied further after breakdown into various groups the numbers were necessarily small. They show, however, that the association of a calcified valve with mitral incompetence did not make a great difference (Table I and Table V). TABle V.-Results in Patients Where There Was Heavy Calcification

\begin{tabular}{c|c|c|c|c|c|c|c} 
& Total & $\begin{array}{c}\text { Op. } \\
\text { Death }\end{array}$ & $\begin{array}{c}\text { Late } \\
\text { Death }\end{array}$ & $\begin{array}{c}\text { Re- } \\
\text { stenosis }\end{array}$ & Good & Poor & Lost \\
\hline $\begin{array}{c}\text { No } \\
\text { M.I. }\end{array}$ & 20 & $3(15 \%)$ & $2(11 \%)$ & $7(41 \%)$ & $3(17 \%)$ & $5(30 \%)$ & 0 \\
$\begin{array}{c}\text { Grade } \\
1\end{array}$ & 13 & 0 & $7(54 \%)$ & $4(31 \%)$ & 1 & 1 & 0 \\
$\begin{array}{c}\text { Grade } \\
2\end{array}$ & 19 & $2(10 \%)$ & $5(29 \%)$ & $7(41 \%)$ & $3(18 \%)$ & 1 & 1 \\
$\begin{array}{c}\text { Grade } \\
3\end{array}$ & 13 & 0 & $8(62 \%)$ & $4(31 \%)$ & 1 & 0 & 0 \\
\hline \multicolumn{7}{c}{ Percentages given are of those surviving operation. }
\end{tabular}

It was thought possible that the inferior results were due to the higher proportion of inadequate "splits" ; there were $33 \%$, as opposed to $16 \%$ in the remaining cases, but this was not reflected in a disproportionately high incidence of restenosis among those where there was no incompetence. The proportion of those treated with the transventricular dilator was very similar in the two groups ( $13 \%$ and $12 \%$ respectively).

The high incidence of inadequate commissurotomies, and the fact that it is now clear that if a valvotomy is done for a calcified valve it must be done with the dilator, led to a further study. All the patients who had such valves and who were treated with the dilator were followed up. As well as the eight already included, there were six whose second operations were done with the dilator and had had their primary operations done by other surgeons, and 12 in this series in whom the first operation was done with the finger and knife and subsequently had second operations carried out with the dilator: 26 operations in all. The results are shown in Table VI.

TABLE VI.-Patients Treated with the Transventricular Dilator

\begin{tabular}{|c|c|c|c|c|c|c|c|}
\hline & Total & $\begin{array}{c}\text { Op. } \\
\text { Death }\end{array}$ & $\begin{array}{c}\text { Late } \\
\text { Death }\end{array}$ & $\begin{array}{c}\mathrm{Re}- \\
\text { stenosis }\end{array}$ & Good & Poor & Lost \\
\hline $\begin{array}{r}\text { All cases with } \\
\text { calcification } \\
\text { before } 1961\end{array}$ & 26 & $\left(\begin{array}{c}2 \\
(8 \%)\end{array}\right.$ & $\begin{array}{c}7 \\
(29 \%)\end{array}$ & $\begin{array}{c}1 \\
(4 \%)\end{array}$ & $\begin{array}{c}10 \\
(42 \%)\end{array}$ & $\begin{array}{c}4 \\
(16 \%)\end{array}$ & $\begin{array}{c}2 \\
(8 \%)\end{array}$ \\
\hline $\begin{array}{r}\text { Cases without } \\
\text { calcification } \\
\text { before } 1961\end{array}$ & 46 & $\begin{array}{c}5 \\
(11 \%)\end{array}$ & $\begin{array}{c}7 \\
(17 \%)\end{array}$ & $\left(\begin{array}{c}1 \\
(2 \%)\end{array}\right.$ & $\begin{array}{c}23 \\
(56 \%)\end{array}$ & $\begin{array}{c}7 \\
(17 \%)\end{array}$ & $\begin{array}{c}3 \\
(7 \%)\end{array}$ \\
\hline
\end{tabular}

Percentages given are of those surviving operation.

The proportions are very similar to those after valvotomy with the finger or knife, with one major exception-namely, that the incidence of restenosis is greatly reduced, and that as a result almost half the patients can still be classified as having good results. On the other hand, the late deaths remain high at $29 \%$, as against the $17 \%$ where no calcification was present.
Thus these figures show that with the transventricular dilator available for the treatment of mitral valve disease complicated by heavy calcification it is probable that, except where there is severe incompetence, valvotomy is at present the procedure of choice even when the calcification is combined with lesser degrees of incompetence. When the late morbidity of prostheses is less this will no longer be so.

\section{Discussion}

There is a considerable volume of literature concerned with the operative mortality after valve replacement, there is also some relating to the results, with particular reference to the complications, but there is remarkably little in which the question posed in this paper is asked-namely, what are the exact indications for mitral valve replacement ?

Clearly, operative mortality is important, and if it were not now quoted in a number of publications (Cooley et al., 1964 ; Effler et al., 1965 ; Kloster et al., 1965) as being below 15\%, replacement would not be as popular as it is. Similarly, if there were no late morbidity among the survivors the indications would not need to be defined so carefully; unhappily this is not so.

A number of papers have been written describing various thromboembolic complications after valve replacement. Figures as high as $50 \%$ have been given by Björk and Malers (1964) and Herr et al. (1965). Chronic haemolysis has also been described (Anderson et al., 1965). These hazards do not of course suggest that the use of prosthetic valves should be abandoned; far from it, but they do imply that the indications for their use should be narrowed so far as is possible.

Large numbers of Starr-Edwards mitral valves have now been inserted, but the indications have not always been clearly defined. Effler et al. (1965) suggested that all cases except those with simple stenosis should be treated with prostheses. Kloster et al. (1965) say that the decision should be left until the valve is inspected, and that then heavy calcification and considerable tissue loss, particularly when the chordae are short, are indications for replacement. Wood et al. (1965) largely agree with these indications, and suggest that valves torn with the dilator may also have to be replaced ; they also say that ever. if there is pure stenosis and the valve is heavily calcified or severely damaged it should be replaced. Ellis et al. (1965) take a more conservative view, saying that many patients with mitral incompetence can be successfully treated with plastic procedures. In each case the suggestions have been based on first principles, and no study similar to the one presented here appears to have been made.

It is hoped that this survey provides some data on which more clear-cut indications can be based. As most of the operations were done by a finger-fracture method, which has now been superseded by the transventricular technique, the figures certainly do not give an overoptimistic view of the results that can be obtained by closed valvotomy. The conclusions which can be drawn from the figures have already been enumerated. Some of them are worthy of further comment.

No patient died in the immediate postoperative period, when it was thought that a severe tear of the valves had occurred, and indeed only one in the whole group of those who had incompetence created died of left ventricular failure soon after operation (in this case an underestimate of the severity of the tear must have been made). Besides this, in by no means all the patients in whom there was thought to have been a serious tear was an open operation subsequently necessary. In a fair proportion (4/12) the long-term results were good. These facts suggest two things: firstly, that caution is needed before a decision on immediate open operation is taken, for it may well be that in view of the unpredictability of the haemodynamic effects of apparently severe tears this should never be done; 
and, secondly, that closed mitral valvotomy is justifiable in the many centres where is it being done without the immediate availability of bypass facilities.

The results following minor tears need explanation. The reason for the high proportion of good results $(62 \%)$ is the low incidence of restenosis. If it is believed that restenosis is an inexorable process after valvotomy, and there is some evidence for this belief, then the larger the orifice left behind after valvotomy the longer it will take for this orifice to be reduced to a critical size. If, as well as the split of the commissures after a valvotomy, there is also a tear of a cusp, then the area of the mitral orifice may be larger than normal, and it will then take longer before the symptoms of restenosis develop.

The conclusions drawn from the facts presented may seem conservative. This conservatism is based on doubts about the long-term results of the use of prostheses, these doubts being enhanced by the high incidence of late emboli and the frequency of chronic haemolysis. No mention has been made of the other methods of treatment of mitral incompetence; in particular the various plastic procedures for valves in which there is little tissue loss may yet prove to be better, but destroyed valves will always have to be replaced.

On the evidence presented here the answer to the question posed is as follows: the mitral valve should not be replaced unless strong indications are present. There is one clear-cut indication: severe mitral incompetence (grade 3) encountered before valvotomy. Less certain indications, where the later complications of prostheses have to be weighed against the long-term results of transventricular valvotomy, are moderate mitral incompetence before valvotomy, particularly when it is associated with heavy calcification of the valve, and severe regurgitation created by valvotomy. Restenosis, minor mitral incompetence either before or after valvotomy, and calcification, however extensive, in the absence of regurgitation do not appear to be indications for valve replacement with the prostheses at present available.

\section{Summary}

In an attempt to define the indications for mitral valve replacement a study was made of 402 patients with mitral valve disease who were treated before the introduction of prostheses, of whom 208 might now be regarded as suitable for the procedure.

Three groups were studied: those with incompetence before operation, those with incompetence after valvotomy, and those with heavy calcification of the valve. In many there was a combination of these conditions.

The results are compared with those in 194 patients who had a valvotomy where none of these conditions were present.
There was found to be a steady deterioration in the results as the grade of incompetence found at operation (117 patients) increased. There were $75 \%$ of late deaths in those patients in whom it was thought to have been severe.

Where incompetence was created ( 71 patients) the results compared favourably with those in whom there was no incompetence. Where grade 1 or 2 incompetence was created the restenosis rate was lower, and even where severe incompetence was thought to have been caused there was no operative mortality and the results were very much better than when severe incompetence was present before valvutomy.

There were 75 patients in whom heavy calcification was found at operation; in 55 there was also mitral incompetence. The results of valvotomy with the finger and knife, which had been used in most of them, were very poor but very much better in those in whom the transventricular technique had been used.

It is concluded that the presence of severe mitral incompetence before valvotomy is the only absolute indication for valve replacement or other form of repair, but that, in view of the high incidence of morbidity after valve replacement, severe calcification, moderate incompetence, whether or not it was associated with severe calcification, or severe tears of the valve at operation were not necessarily indications for a prosthesis. It was also concluded that restenosis, simple calcification without incompetence, and minor degrees of incompetence should not be treated with prostheses.

My thanks to Dr. W. Sommerville and Dr. M. Honey for helpful criticism and to my other colleagues at the Middlesex and the London Chest Hospitals for their help in treating these patients.

\section{REFERENCES}

Andersen, M. N., Gabrieli, E., and Zizzi, J. A. (1965). F. thorac, cardiovasc. Surg., 50, 501.

Belcher, J. R. (1956). Lancet, 2, 7.

- (1964). Brit. Heart Y., 26, 513.

- and Gupta, R. L. (1964). Brit. med. F., 1, 871. B;örk, V. O., and Malers, E. (1964). 7. thorac. cardiovasc. Surg., 48,
625 .

Cooley, D. A., Nelson, T. G., Beall, A. C., and DeBakey, M. E. (1964). Dis. Chest, 46, 339. Effler, D. B., Favaloro, R., and Groves, L. K. (1965). Ann. thorac.

Ellis, F. H., Callahan, J. A., McGoon, D. C., and Kirklin, J. W. (1965). New Engl. F. Med., 272, 869.

Herr, R., Starr, A., McCord, C. W., and Wood, J. A. (1965). Ann. thorac. Surg., 1, 403. Kloster, F. E., Bristow, J. D., and Griswold, H. E. (1965). Progr.
cardiovasc. Dis., 7, 504.

Wood, J. A., Starr, A., McCord, C., and Herr, R. (1965). Aer. F. Surg.,
110, 257 . 